\title{
R,D\&I in Electric Sector: a Management Model
}

\author{
Edmilson Alves de Moraes', Carmen Augusta Varela²
}

\begin{abstract}
This study was carried out with the support of the companies of Eletrobras (Chesf, Furnas, Eletronorte and Eletrosul) and seeks to develop an integrated management model that incorporates technology and innovation. The model should be concerned with the performance of companies, aligning R, D\&I [Research, Development and Innovation] projects with business strategies. The project was undertaken by an in-depth bibliographical review of the subject and a series of guided interviews. These interviews were conducted in both national and international companies that were regarded as innovative in several different sectors, in an attempt to identify practices that could be employed by companies in the electric sector. The findings of this research allowed the development of an integrated R,D\&I Management model which is formally set out here as the results of this study.
\end{abstract}

Keywords: projects; R,D\&l; electric sector; model; management; innovation; investment; portfolio; strategy; strategic decisions.

Centro Universitário da FEI- SP - Department of Business Studies - Rua Tamandaré, 688 - Liberdade- São Paulo-SP- Brazil- CEP: 0I525000- Phone: 55(I I) 3274-5200.E-mail: 'edmilson@fei.edu.br, ${ }^{2}$ cvarela@fei.edu 


\section{Introduction}

From 2004 to 2006, Chesf, Furnas, Eletronorte and Eletrosul (companies owned by Eletrobras Group) supported by CGTEE, Copal, Electronuclear carried out a research project with Getulio Vargas Foundation researchers with the aim of developing a model for technology and innovation management.

This project, which was called DEG (Strategic Management Guidelines), arose from the interest of the companies cited above in carrying out an in-depth study of technology and innovation management practices in some well known innovative firms, in Brazil and abroad. The project was part of the National Electric Energy Agency (ANEEL) - Cycle 20022003 - R, D\&I project portfolio. The purpose of the DEG Project was to develop an integrated Research, Development \& Innovation model for the companies of the Eletrobras Group. The project comprised the following stages:

- $\quad$ Stage I: In this stage it was done a critical review of the most recent literature on Technology Management and Innovation Management focusing in its conceptual development.

- $\quad$ Stage II: The main objective of this stage was to determine how companies and national or international research centers, which were benchmarks of excellence, proceed with matters regarding technology and innovation management.

- $\quad$ Stage III:The Integrated Model of Technology and Innovation Management was developed in this stage of the project and adapted to some specific features of the electric sector.

\section{Conceptual framework}

According to Schumpeter (1988), one of the first authors to study the relationship between innovation and the economic development, an innovation or a new combination, can occur in five different situations: a) the introduction of new goods; b) the introduction of a new production method; c) the opening up of a new market; d) the discovery of a new source of raw materials, and e) the establishment of a new kind of industrial organization in some sector of the economy.

It's important to stress that an invention or a new idea may not necessarily lead to an innovation. Before an idea to be turned into an innovation, there must be a great effort to implement this new idea, and this idea has to be accepted by the social system to become an innovation (Vasconcellos, 2009; Barbieri and Álvares, 2003). According to the Innovation Forum of EAESP-FGV, an innovation can be expressed in the following equation: Innovation = idea + implementation + results.
The Oslo Manual (1997), published by the Organisation for Economic Co-operation and Development (OECD), states that innovation plays a key role in a knowledge-based economy but that until then the way it operated was still not well-known. According to this publication:

At the macro-level, there is a substantial body of evidence that innovation is the dominant factor in national economic growth and international patterns of trade. At the micro-level - within firms - R\&D is seen as enhancing a firm's capacity to absorb and make use of new knowledge of all kinds, not just technological knowledge. Other factors which influence firms' abilities to learn are also seen to be of fundamental importance. Ease of communication, effective channels of information, skills transmission and the accumulation of knowledge, within organisations and between them, are highly important. In particular, management and an appropriate strategic outlook are key factors. They determine much of the scope for the external linkages and the positive attitudes inside firms that promote receptivity to the adoption of improved practices and improved technology... (OECD, 1997, p. I5).

Some studies (Souder and Sherman, 1994; Tidd, 2000; Tidd, Bessant and Pavitt, 2008) provide evidence that in our globalized world which is constantly undergoing change, the capacity for innovation is responsible for much of the success of an organization. The launching of new products and services allows an organization to capture a greater market share and thus increase its profitability.

Tidd, Bessant and Pavitt (2008) divide innovations into four different categories which are also called the 4 P's of organizations. These are as follows: a) product/services innovation; b) process innovation; c) position innovation, which characterizes the way that the goods and services are provided to the market; d) paradigm innovation - which according to the authors, reflects changes in the underlying mental models which shape what the organization does. The authors add that in each of the 4 innovation P's, there is a range of incremental changes as well as radical changes.

The Resource-Based Theory (Barney, 1991) employs a concept where every company has a bundle of essential skills that must be aligned to strategic planning and have to back up the strategy implementation and all the activities carried out in the organization. This theory suggests that innovation should be aligned with the main activities of the business, both with regard to technological innovations and management innovations (Hamel and Prahalad, 1995).

Based on the concept of organizations as networks and the Neo-Institutional Theory, organizations create their own environment by means of an intermediation with public bod-

ISSN: 07 I8-2724. (http://www.jotmi.org)

Journal of Technology Management \& Innovation (c) Universidad Alberto Hurtado, Facultad de Economía y Negocios. 
ies, suppliers, customers and strategic alliances with other organizations. The ability to handle paradoxical situations (planning/improvisation; integration/differentiation; centralization/decentralization) is one of the most important capabilities an organization should have to support innovation (Vasconcelos and Vasconcelos, 2004). In the opinion of Freeman and Soete (1997), the effective involvement of three players is required for a successful system of innovation to occur: the government, universities and companies.

Innovation has a close relationship with knowledge management. Any organization that attempts to employ some of the various kinds of knowledge to develop an innovation, is subject to a high degree of uncertainty and risk because this decision may or may not be successful. With regard to its intrinsic features, incremental innovations cause a lower degree of uncertainty than radical innovations because they set out from something that is already known and has been gradually improved, which makes it easier to forecast the costs and the possible benefits that can be derived (Tidd, Bessant and Pavitt, 2008).

Regarding knowledge, it is important to enhance the partnership among business firms and Universities once the main strength of the academic world lies in the quality of its human resources which should be adapted to address the needs of companies to develop innovations. Chaddad and Andreassi (2002) argue that, although they might be induced, innovations demand model should prevail over supply demand model. Segatto and Sbragio (1996) state that while the Universities look for companies to have access to practical knowledge about existing problems, to incorporate new information in its teaching and learning (and also obtain funding and make the university better known), the main driving-force that persuades companies to turn to universities and research institutions is as follows: to establish contact with highly qualified human resources, solve technical problems which have led to a need for research, reduce the costs and risks entailed in the R,D\&l field, gain access to the new knowledge acquired in the Universities and earmark students for future recruitment. Although these motivating factors are not entirely incompatible, they are certainly different and without an efficient management of these conflicting areas, insuperable obstacles may raise ending up the partnership.

Fonseca (1998) states that to develop a pattern of lasting relationships between the universities and the business firms, is necessary to define policies to support the combined interaction involving three categories: politic-normative, creating instruments to support the innovative activities carried out in partnerships; administrative mechanisms that creates some cultural, motivational, behavioral and technical conditions that are conducive to partnerships and for undertak- ing projects of technological innovation; and organizational structures which create a formal basis to make it feasible to carry out a range of projects and develop innovations.

One of the goals of the strategic study conducted by the Brazilian Ministry of Planning, Budget and Management (2008) is to help the Brazilian system of science, technology and innovation to achieve higher standards of development. To do that it states that is important to invest in new renewable sources of energy, and new technologies that are lowintensive regarding the use of natural resources and energy. To face this challenge it is important to the companies in the Brazilian electric sector to cooperate each other and develop an integrated R, D\&I management system that could help them to manage effectively this process.

\section{Methodology}

The DEG project methodological basis was an inductive study and thus the research began by conducting a wideranging bibliographical survey of the subject. This bibliographical review, together with the results of the field study, provided the basis for formulating the R, D\&l Model to be implemented in the companies in the Eletrobras Group.

It was decided to adopt a qualitative methodological approach for carrying out the field study. The researchers also sought to understand the environmental and organizational context, as well as to analyze the relevant meanings for the innovative processes in the researched institutions by using the method of a case study.

According to Yin (200I), the main ways the case study can be used are as follows: a) to explain the causal links in the interventions of real-life situations that are too complex for the experimental strategies; b) to describe an intervention or situation and the real-life circumstances in which it occurs; c) to illustrate certain topics within an assessment of a descriptive kind and d) to explore those situations in which the real situation is being assessed and a simple and clear set of results is not shown. This method is quite useful when answers are sought to questions related to "how" and "why" certain phenomena occur.

In carrying out the processes of innovation, institutions known to be "excellent" were selected with the purpose of identifying their best practices and thus being able to seek a realistic picture of the benefits and drawbacks and particularly the strong points in favor of implementing the models. In undertaking this, it was important to ensure that semistructured interviews were conducted in a realistic way with the directors, managers and/or researchers and specialists involved in innovation practices in research institutions. 
The compilation of these "best innovative practices" both technical and organizational was aimed at finding the most useful examples. After that an innovation model that could be adapted to companies in the Brazilian electric sector was developed. The primary data were obtained by semi-structured interviews with people selected in the researched organizations. The interviewees were directly responsible for or involved in the innovative processes of that institutions.

The secondary sources of the analysis included internal and external documents that allowed the identification of the key factors for innovation development in the institutions, their "best practices" or activities in which they showed some degree of excellence. This analysis had also shed some light about problems, difficulties or obstacles to innovation.

The researchers sought to find out to what extent the innovation models described by the institutions were in fact employed and what practical difficulties they experienced in their implementation.

On the basis of the experience and involvement of the participants in the project supported by the bibliographical research, a blueprint version of the instrument for data collection was prepared - in this case a set of open answer questions - and this was validated by the companies. The company was given these questions in advance so they could prepare themselves for the visit, allowing the process to run more smoothly.

It was decided not to record the interviews so as not to inhibit the interviewees. As the visits were monitored by several members of the team, the relevant factors of the research question were noted down by the participants.

Apart from the epistemological restraints arising from the impossibility of generalizing the data, there was another technical limitation which was the fact that the study was not carried out from a neutral standpoint. In other words, from the standpoint of the "interpretationist" paradigm, the study sets out from an assumption that the researcher observes the organizational and environmental contexts and also interprets the information that is conveyed during the interviews, which means that there may be an interpretative bias arising from his technical and socio-cultural background. In this study, two procedures were followed in an attempt to limit the extent of this bias: (a) after the interviews and at the time of writing up the record of each interview, the participants were shown the notes so that they could confirm their observations and (b) these observations were also set against information obtained from secondary data - company reports, leaflets, internet sites, explanatory material supplied by the interviewees, etc.
After the method had been established, the next stage was to identify the institutions that would be the object of the research. Nine institutions were chosen based on several factors, among them, their links with the energy sector, the importance of their line of business and their R, D\&I activities. Nine visits were carried out, six to Brazilian institutions and three to institutions abroad.

A descriptive analysis and content analysis were employed for the primary data processing. A documentary analysis and content analysis were required for the secondary data processing. Among the various techniques for conducting a content analysis, a categorical thematic analysis was chosen because it allowed units of meaning to be identified. The analysis of categories was prepared on the basis of data retrieved from the reports and notes of the researchers.

The data were collated and grouped by categories and subjects with a view to forming a typology that referred to the patterns that could be found on several aspects of innovation observed in the institutions.

The analysis of the replies obtained from the interviews was carried out by putting them in a comparison matrix in which the answers to the same item from various institutions are juxtaposed and compared with each other to allow general typologies to be obtained.

\section{Findings and Analyses}

Analyses about various factors were conducted but in this paper we concentrate on the analyses of how innovation takes place in companies, stressing the relationship between radical and incremental innovation and centralization or decentralization. Nine national and international companies were researched and in Table I below, there is a list of the items observed in the selected companies selected.

Following the procedures set out in the methodology, a parameterization of the analytical categories was conducted on the basis of a I-5 scale. Two analytical categories were identified: radical innovation $v$ incremental innovation (where $\mathrm{I}=$ the entire emphasis is on radical innovation and $5=$ the entire emphasis is on incremental innovation) and centralization $v$ decentralization of the research and development process ( where $I=$ the entire structure is centralized and $5=$ the entire structure is decentralized). The grading performed by these nine companies can be found in Table 2 below.

With the exception of Gerdau and Embrapa, it can be determined from Table 2 that a state of equilibrium can be found between the choice of the radical and incremental innovation in the institutions analyzed. One explanation for 


\begin{tabular}{|c|c|}
\hline INSTITUTION & ITEMS OBSERVED \\
\hline BRASILATA & $\begin{array}{l}\text { The innovative ideas in Brasilata occur naturally and are encouraged at every decision-making level. } \\
\text { The company believes in team spirit and encourages all its personnel to work together and come up } \\
\text { with the maximum number of ideas that they can.All the employees are regarded as inventors and } \\
\text { recognition of this is made publicly. The process of innovation is characterized by sequential and con- } \\
\text { tinuous actions arising from an adaptive and flexible management stance which has influenced the rise } \\
\text { of a sequence of several other radical and incremental innovations. }\end{array}$ \\
\hline CEMIG & $\begin{array}{l}\text { CEMIG has a process of technological management that passes through four distinct phases: a) Stra- } \\
\text { tegic analysis, where macroeconomic scenarios are created; b) the phase called a Technological Audit } \\
\text { where an analysis of the context is carried out and an attempt is made to assess the business itself } \\
\text { of a company by determining what are its strong and weak points and what its partners and compet- } \\
\text { itors are like with regard to these, and making an appraisal of the principal forms of technology that } \\
\text { support the business. The technologies are classified into two kinds: key technologies and emerging } \\
\text { technologies. The former has the potential to leverage the competitiveness of the company since the } \\
\text { emerging technologies can change the whole business where the company operates; c) in the third } \\
\text { phase, action plans are drawn up which must take account of what funds the company has available, } \\
\text { what priorities have been agreed and what qualified skills can be found in the company and among the } \\
\text { partners. Based on this survey, recommendations are made about what areas should be carried out } \\
\text { with partners and what should be purchased, and d) the fourth and final phase concerns implemen- } \\
\text { tation and monitoring. In this phase, correction systems are undertaken together with the analysis of } \\
\text { the results. }\end{array}$ \\
\hline DU PONT & $\begin{array}{l}\text { Visits were made to two research and development paint and dye laboratories both for the car indus- } \\
\text { try and for printing (paper, plastics and fabrics). The labs that were visited were Marshall R, D \&I Lab- } \\
\text { oratory and the laboratories of the Experimental Station. They were found to be carrying out work } \\
\text { in both radical and incremental innovations. These innovations are always geared towards tackling a } \\
\text { problem that has been identified or found by customers. The projects are classified in three distinct } \\
\text { categories: a) R,D\&l, where research has been conducted into the technical basis of the problem or } \\
\text { project; b) Sales Technical Expenses (STE) designed to cater for the market with new products that } \\
\text { will be launched , and c) Manufacturing Technical Expenses (MTE), which the purpose is to improve } \\
\text { the "scalability" of the products that already exist or rather, improve their performance in the manu- } \\
\text { facturing processes by reducing costs and improving the performance of the systems. }\end{array}$ \\
\hline EMBRAER & $\begin{array}{l}\text { The R,D\&l activities of Embraer can be divided into two areas: competitive technological intelligence } \\
\text { and the development of products. This company has } 36 \text { employees and "borrowed" personnel from } \\
\text { functional areas to carry out projects. } \\
\text { Investment in R,D\&I usually represents between } 7 \% \text { and } 10 \% \text { of the gross revenue of a company and } \\
\text { has been divided between the areas of competitive technological intelligence and the development of } \\
\text { products, in proportions of } 10 \% \text { and } 90 \% \text {. In some sectors like the pharmaceutical and microelec- } \\
\text { tronics industry, only a small number of the technologies investigated turned out to be used in the } \\
\text { products but in the aeronautical sector, including Embraer, the situation is different because there is a } \\
\text { wide range of products and even when a technology may not be applicable to one product, it probably } \\
\text { will be to another.The decisions about which technologies will be funded are made on the basis of } \\
\text { a "Roadmap Technology" which has a time-span of } 3 \text { to } 5 \text { years. This "roadmap" is drawn up for a } \\
\text { long-term scenario ( } 20 \text { years), as well as for the present situation. The "roadmap" for products is also } \\
\text { employed and plays an important role in the preparation of the technological "roadmap". }\end{array}$ \\
\hline EMBRAPA & $\begin{array}{l}\text { The process of technological innovation is viewed by the company as a means of transforming } \\
\text { knowledge into economic and social value and includes the following phases: identifying, creating and } \\
\text { adopting innovations. The Master Plan IV (2004-2007) was designed to make sustainable development } \\
\text { plans feasible for rural space and was operated in accordance with government policies which laid } \\
\text { emphasis on social inclusion, food security, market expectations and the quality of the environment. } \\
\text { Embrapa regarded the capacity to innovate as involving the following: the employment of knowledge } \\
\text { for problem-solving and the search for new opportunities; the generation of technology by means } \\
\text { of new goods, processes, services, systems and businesses, as well as making use of opportunities to } \\
\text { obtain economic and social benefits (such as social welfare). }\end{array}$ \\
\hline
\end{tabular}




\begin{tabular}{|c|c|}
\hline ERICSSON & $\begin{array}{l}\text { All the R, D\&I projects are closely aligned with the strategic planning of the company in terms of "core } \\
\text { competencies". The company defines what are its areas of expertise; its priorities and main skills, and } \\
\text { its innovations both with regard to products and internal processes must be aligned with this set of } \\
\text { key competencies. If this does not occur, the project is not accepted. In this way the R,D\&l projects } \\
\text { and the innovations in the products and manufacturing processes that arise from them, are carried out } \\
\text { within the company in the light of this close link with strategic planning and the key competencies de- } \\
\text { fined by the organization. The company invests } 7 \% \text { of its gross revenue in Research and Development. } \\
\text { The company has four research centers, one of which is in Canada. In this way, R,D\&l in the company } \\
\text { is organized by means of projects which involve organized research groups in "networks" and often } \\
\text { include more than one laboratory. Thus, "intelligent research networks" are established or in other } \\
\text { words, areas of expertise and scientific research, which combine researchers from various labora- } \\
\text { tories with university researchers, who have been chosen to take part in specific research programs } \\
\text { sponsored by the company. Scientific debates and research are carried out around areas of technical } \\
\text { expertise and the specific skills of the researchers. There is a high degree of specialized knowledge. }\end{array}$ \\
\hline GERDAU & $\begin{array}{l}\text { The innovations in Gerdau are preeminently organizational.With the exception of Aços Finos Piratini, } \\
\text { which supplies steel for the automobile industry and includes the specialist area of Gerdau, in the } \\
\text { others units of the company the activity of R,D\&l is carried out in the area of Production/Engineering. } \\
\text { Strictly speaking there is no area of R,D\&l and in fact it is much more "D" than "R". } \\
\text { In carrying out its activities, the company employs a matrix structure. In one axis, there are business } \\
\text { operations - Aços Longos Brasil in South America and North America, Açominas and Aços Especiais. } \\
\text { In another axis, there are the } 20 \text { operational procedures - Marketing, Logistics, Supplies, Legal } \\
\text { Advisory Dept., Management Technology, Computer Science, Social Communications, Finance, etc. } \\
\text { Thus, there is a committee of five members of the marketing staff, for example, who discuss ques- } \\
\text { tions related with the area, involving } 5 \text { business operations, at the same time that there is a committee } \\
\text { of } 20 \text { employees discussing } 20 \text { distinct topics concerning a single business transaction (Açominas, for } \\
\text { example). }\end{array}$ \\
\hline IBM & $\begin{array}{l}\text { Innovations in IBM are carried out for families of products. Some worldwide laboratories are spe- } \\
\text { cialized in one type of innovation and have "affiliate laboratories", which also conduct research in the } \\
\text { same area in another part of the world. The laboratories are constantly exchanging information about } \\
\text { techniques and form a global "network" for the kinds of innovation carried out in these laboratories. } \\
\text { In the case of IBM Toronto, the laboratories involved in the development of this type of software are } \\
\text { located in California, Kansas and Japan. } \\
\text { The projects are all coordinated with the strategic planning of the company and the definition of its } \\
\text { "core competencies". The company has defined some of its key competencies as follows: a focus on } \\
\text { winning; a focus on the customer; innovative thinking; a capacity for achievement; the leadership of the } \\
\text { teams; integration of the Team for Innovation; a capacity for decision-making and replying to questions; } \\
\text { and a commitment to the organization. The company seeks personnel who possess these personal } \\
\text { skills and also trains their staff to acquire them. }\end{array}$ \\
\hline SIEMENS BRASIL & $\begin{array}{l}\text { The Brazilian affiliate follows a corporate strategy in matters concerned with research development } \\
\text { and innovation and its activities are governed in the same way as those observed in the Corporate } \\
\text { Technology in Erlangen. Siemens is one of the companies that invest most heavily in R,D\&l around the } \\
\text { world, with investment figures in the order of } 6 \text { billion dollars in } 2003 \text {, which led to about } 8000 \text { in- } \\
\text { ventions and } 4000 \text { patents. Its focus in research is essentially internal with large research laboratories } \\
\text { being assembled, accompanied by a system of management which regards them as business units. The } \\
\text { research carried out can be classified as applied research. The innovations undertaken by Siemens are } \\
\text { quite decentralized and are spread out in dozens of research and development centers concentrated } \\
\text { in Germany, the US, China and India. Brazil has four of these centers. Most of the work is centered } \\
\text { on incremental innovation with a direct application to goods sold by the company (this description } \\
\text { applies to all the units in Siemens). }\end{array}$ \\
\hline
\end{tabular}

Table I: How innovation takes place companies. Source: compiled by the author

ISSN: 07 I8-2724. (http://www.jotmi.org)

Journal of Technology Management \& Innovation (C) Universidad Alberto Hurtado, Facultad de Economía y Negocios. 
this result might be the fact that, since the selection of these institutions was based on the degree of importance they attached to the question of innovation, they preferred to make a significant investment in radical innovations, with long-term prospects, and aimed at ensuring markets in the future. Five of the nine companies chosen had a structure of innovation that was entirely decentralized.

The institutions varied in the extent to which they relied on the formation of partnerships for carrying out innovations. Whereas some had a reasonably well-structured R,D\&I sector, with a focus on internal development of innovations and without relying on partnerships (or with a very restricted use as in the case of DuPont), others adopted a more open perspective by encouraging R,D\&I sectors and allying them with research centers and universities as a means of leveraging and carrying out innovations (such as Embrapa, for example). Some institutions that had R,D\&l sectors tend to decentralize their plants, like Siemens, IBM or DuPont, which spreads the development of knowledge and distinct competencies to various centers around the world.

The choice of the form of technological development is not a dichotomous decision since it has to be made in a way that allows the company to establish itself as a developer or purchaser of technology. Cemig divided its R,D\&l projects in two categories: the first called the expenditure project was aimed at buying technology and the second called the investment project was aimed at investing in new technology, by adopting an intermediate and flexible position that depended on what the company saw as its needs, as well as the availability of both financial and human resources. Companies like Du Pont that believed that they had a leading knowledge in certain areas, did not see any need to seek agreements outside their research group.

Companies that are highly structured in the R,D\&l sector tend to follow formal and cyclical procedures with regard to planning and technological management and usually ensure that these coincide with periods when strategic planning is reviewed over the short or long term. These companies ensure that all the phases of the process are well-structured with a schedule for carrying out each stage, and personnel previously assigned for the work by committees that are responsible for overseeing the whole process. In other companies, the procedure is more informal and continuous, as in the case of Brasilata, where the search for innovations is conducted on a day-to-day basis and where the innovative process does not follow a formal procedure but is evolving and fluid.

\section{Proposed Model}

A number of premises were taken into account when forming the technological management and innovation model: it is a model that is planned, centralized and aligned to strategic planning and the decentralized management of the projects; the model rests on the assumption that the relationship between the companies of Eletrobras Group, is a relationship which is established by the interaction of the "holdings" committees; the model envisages enough flexibility for the inclusion of emerging strategies; a pro-active management is implicit in the model for the relationship between the area of R,D\&I with HR and knowledge management; a framework is implicit in the model to allow the company to disseminate the results of knowledge or to protect it; the model was designed to include both internal and external clients; at every stage, the model assumes an incorporation of all the principles that can provide guidance for socio-environmental responsibility.

The proposed model is displayed in Figure I. It should be stressed that the model that is shown can be applied to any company in Eletrobras Group because its main feature is to show the macro-functions involved in the technology and innovation development by establishing that these can be

\begin{tabular}{|l|l|l|}
\hline Institution & Radical (I) v incremental innovation (5) & Centralization (I) v decentralization (5) \\
\hline Brasilata & 3 & $\mathrm{I}$ \\
\hline Cemig & 4 & $\mathrm{I}$ \\
\hline DuPont & 2 & 5 \\
\hline Embraer & 3 & $\mathrm{I}$ \\
\hline Embrapa & $\mathrm{I}$ & 5 \\
\hline Ericsson & 2 & 5 \\
\hline Gerdau & 5 & $\mathrm{I}$ \\
\hline IBM & 2 & 5 \\
\hline Siemens & 2 & 5 \\
\hline
\end{tabular}

Table 2: Grading of the institutions according to the analytical categories. Source: Compiled by the authors

ISSN: 07I 8-2724. (http://www.jotmi.org)

Journal of Technology Management \& Innovation (c) Universidad Alberto Hurtado, Facultad de Economía y Negocios. 
arranged in accordance with the different hierarchies and structures of the company.

The model anticipates a strong reaction with stakeholders in view of the influence that these can exert on the electric sector. The role of the government and the management of the image of the company in the eyes of society, are important factors that must be taken into account to allow access to resources and the structuring of policies with regard to innovation.
It also envisages that interactions will be carried out with the holding company in matters concerning the possible demands made by the stakeholders so that they can be in tune with the entrepreneurial strategy of Eletrobras Group. These activities will be carried out by the senior management at a meeting of the Board of Directors of the Eletrobras System (CONSISE), which consists of the presidents of the companies in Eletrobras Group and the directors of the holding company.

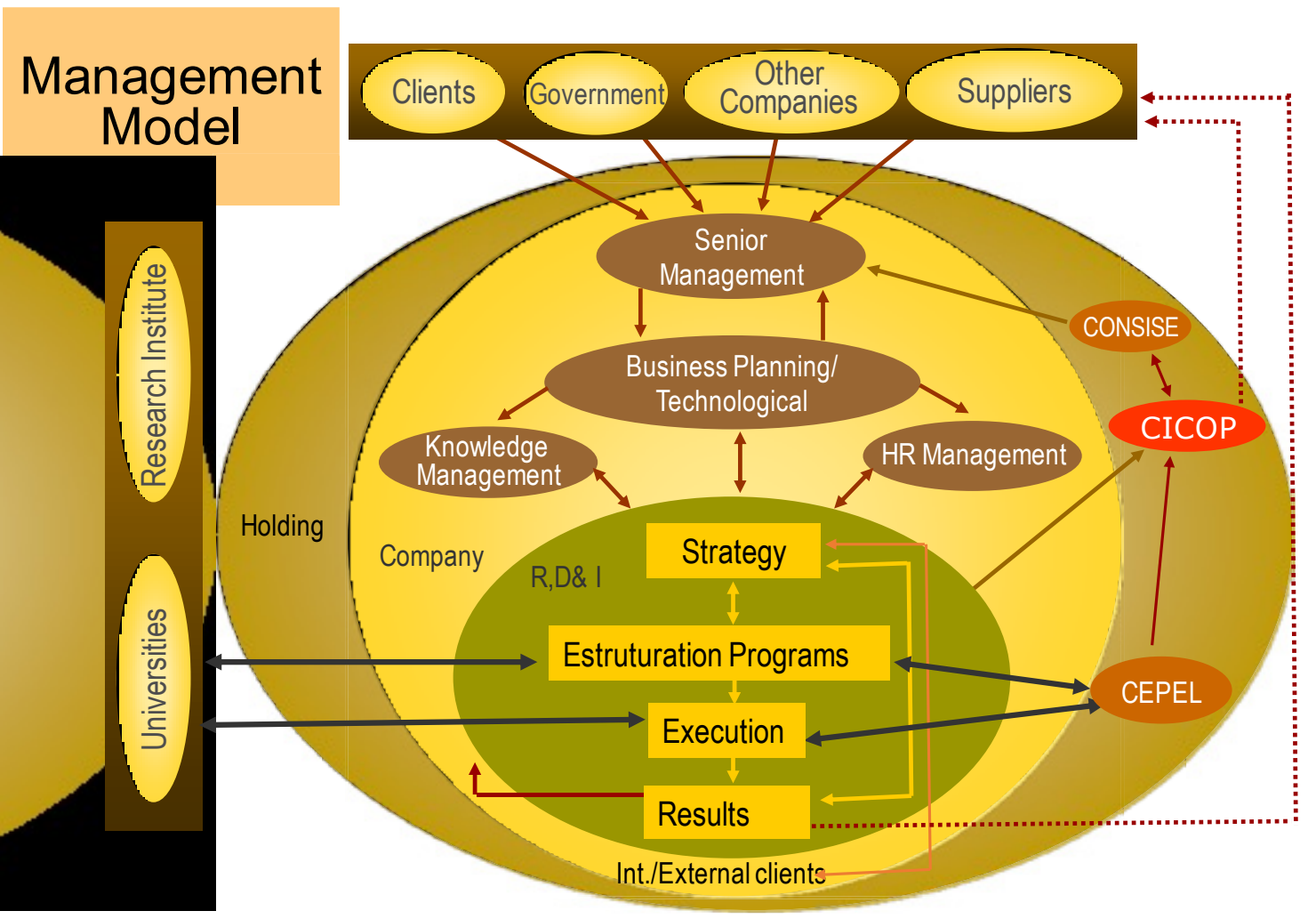

Figure I. Proposed Model for the Management of Technology and Innovation. Source: compiled by the authors.
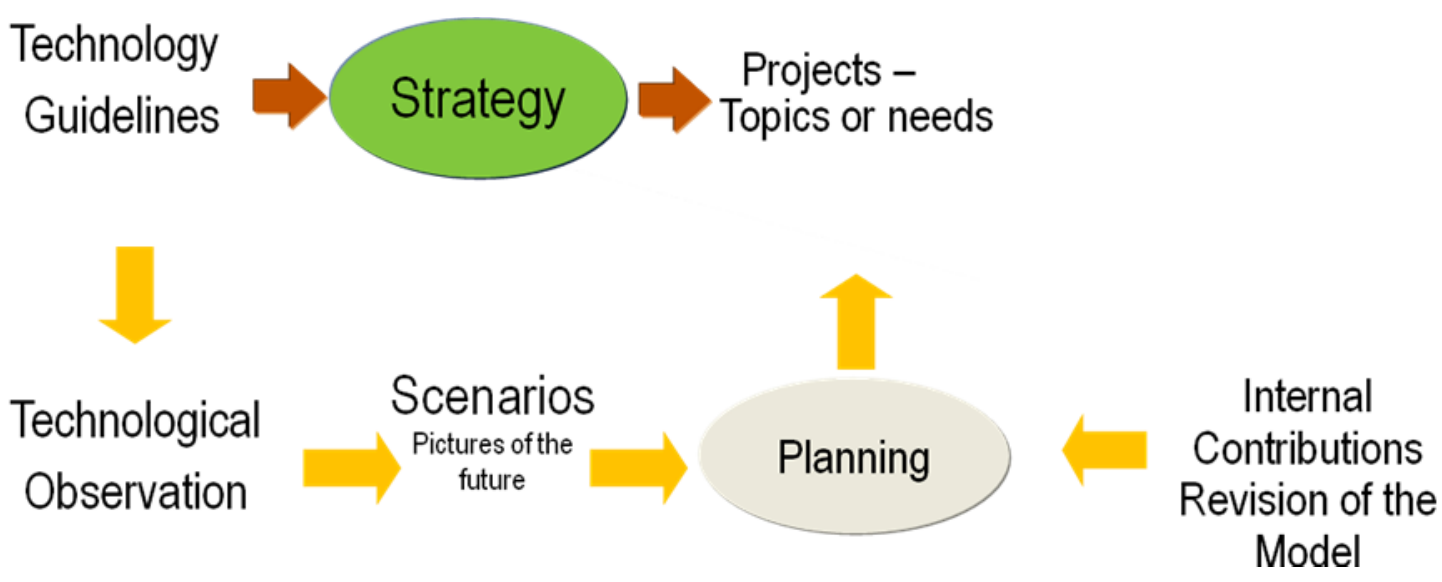

Figure 2:The R, D\&I Strategy. Source: compiled by the authors. 
The management area of R,D\&l will also operate together with the holding company by means of Cicop (Research, Development and Innovation Corporate Integration Committee) to ensure the establishment of new technological policies will be accepted by the Committee of Strategic Planning of Eletrobras System (COPESE), the main aim of which is the provision of subsidies for drawing up a strategic plan for the Group and giving support to its management.

It is of crucial importance that the focal point of the activity should be based on entrepreneurial planning so that the activities involved in technological and innovative development can take shape in the company as well as on attracting the necessary personnel and having a suitable framework. In this way, they can inevitably expect the support and participation of the senior management and their approval, from the policies needed for the structuring of the activity and strategies of promotion to the activities that will lead to the technological development of the company and as a result, to innovation.

To carry out the deployments in the sphere of Research, Development and Innovation, there is a phase of technological observation which precedes the planning and is outlined in Figure 2.

The technological observation phase predicted in the model consists of the mapping and monitoring of the key potential technologies that can be found in various national and global scenarios and which reflect what the large corporations, universities and research centers are carrying out in the realm of technological development and innovation. Technological observation produces a series of possible scenarios which are also called "pictures of the future", which suggests setting up a task force to act in this area.

The planning phase will have to be carried out by the Technological Committee of companies that will be aided by CEPEL through invitations from universities, research institutes and the government, as well as by members of communities of practices. Once the projects have been defined - as topics or needs - and the area responsible for R,D\&l in the company (with the support of members of the communities of practice) have begun the structuring of the programs, the framework outlined here for the source of funding can be understood.

This is followed by the forecasting, selection and approval of the proposals culminating in the relationship between the R,D\&l programs accepted. Figure 3 outlines the mains stages of the structuring of the programs. With regard to the analysis of the proposals, it is suggested that there is a need to establish methodologies, procedures and schedules to identify and assess the competencies that exist for undertaking the $R, D \& I$ projects and which can be employed by companies.

The R,D\&I programs that are approved are forwarded to the R,D\&I management which in its turn appoints the supervisors of the projects and their formal substitutes. The model envisages that the undertaking of the project should be divided into two phases: the hiring of staff (strictly speaking) and the management of projects as outlined in Figure 4.

The hiring of the projects is carried out by the R, D\&I management or even by specific personnel areas with the sup-

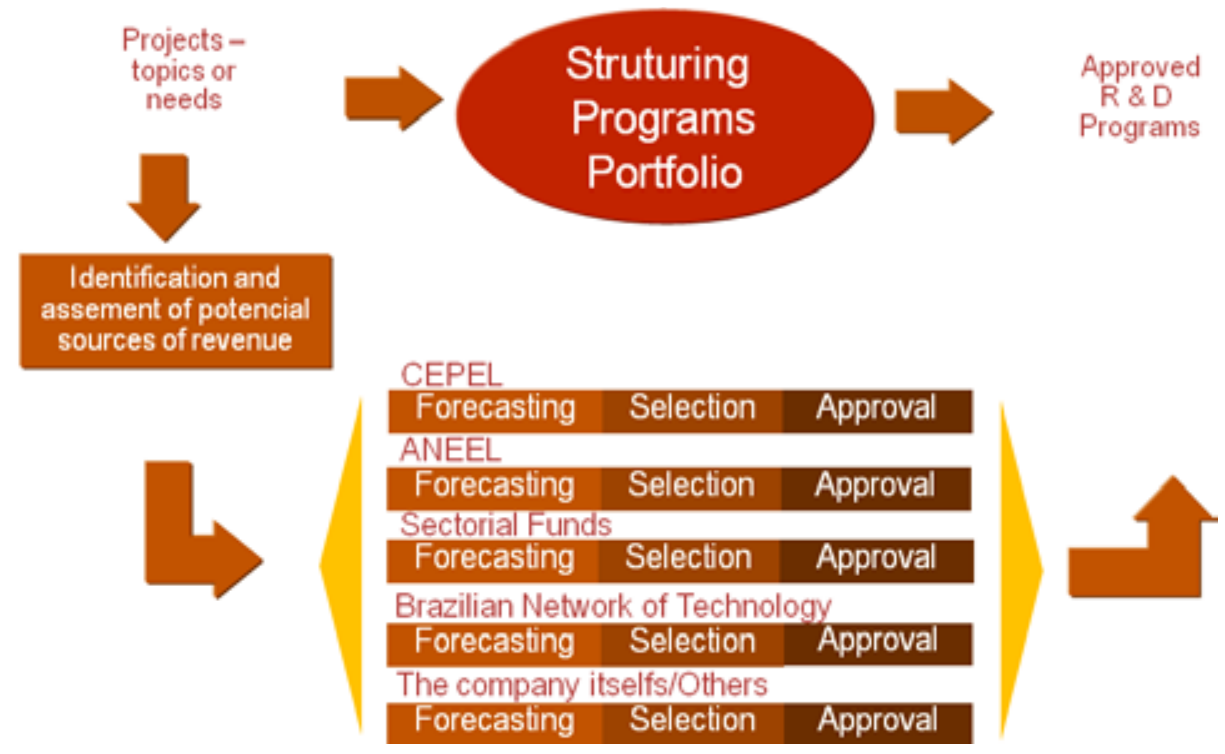

Figure 3:The structuring of the programs. Source: compiled by the authors.

ISSN: 07 I8-2724. (http://www.jotmi.org)

Journal of Technology Management \& Innovation (c) Universidad Alberto Hurtado, Facultad de Economía y Negocios. 
port of those responsible for the supervision of the project. Its main activities concern the interaction with the institutions involved in hiring personnel, requesting documents, certificates, business conditions, contracts etc - as well as the formal hiring of employees and the signing of contracts or agreements in compliance with the legal regulations of each company. Once the contracts have been signed, there begins the management stage of the project and those responsible are the members of the R, D\&l management team and the various supervisors of the projects that are in related areas together with their formal surrogates.

Once the product or knowledge generated by the product, has been obtained, the next stage is the dissemination, protection and assessment of the model, as can be checked in Figure 5 below.

Dissemination can be found in both the internal and external communications of the company. In the case of internal communications, it is achieved at the end of the project by the members of the R,D\&I management team. The exter- nal communication also occurs at the end of the project provided that the issues regarding protection are assessed by the members of the R,D\&l management team and the supervisors of the project.

Protection also takes place at the end of the project and can occur in two ways, either by means of patents or by trade secrets. If it is decided to do it through patenting, the members of the R, D\&I management team and the supervisors of the project, together with the legal advisors of the company, must undertake activities related to putting protective measures into effect.

If the decision is for trade secrets, the knowledge is guarded for internal use, or made available or shared exclusively with companies in Eletrobras Group, or else used to increase the stock of knowledge for future use.

The assessment can be subdivided into the evaluation of the results of the program and the evaluation of the management model (strictly speaking). The aim of the former is to

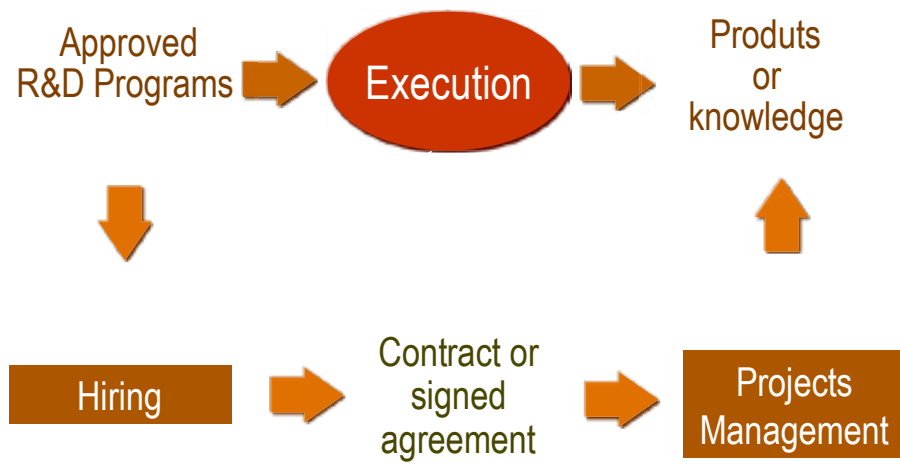

Figure 4: Execution. Source: compiled by the authors.
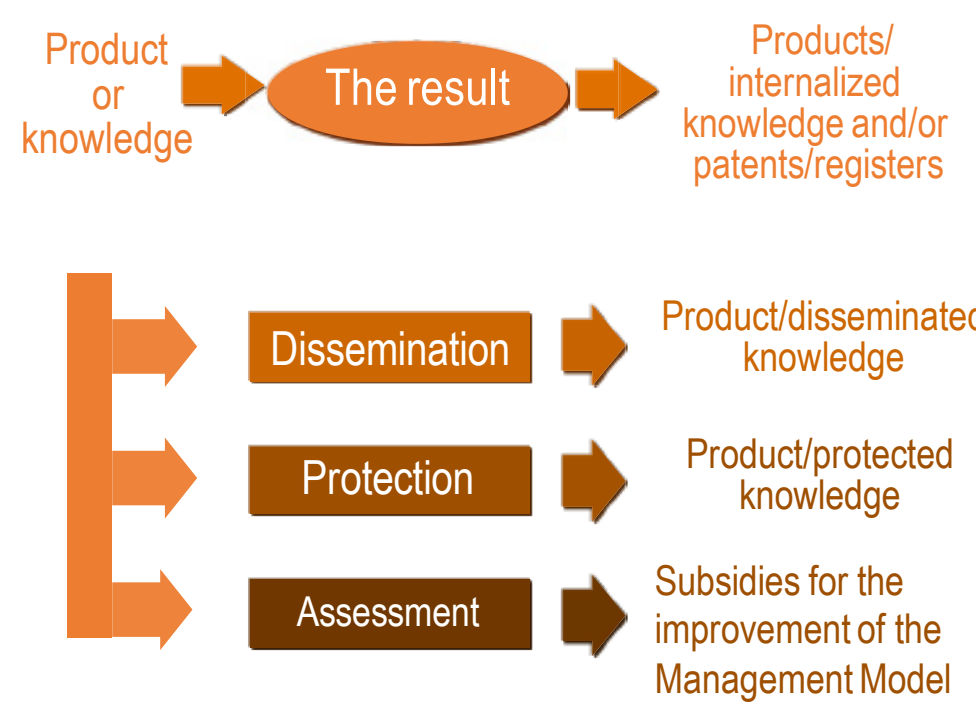

Figure 5:The Result. Source: compiled by the authors.

ISSN: 07 I8-2724. (http://www.jotmi.org)

Journal of Technology Management \& Innovation (c) Universidad Alberto Hurtado, Facultad de Economía y Negocios. 
carry out a survey of "lessons learnt" and must be undertaken at the end of the project by members of the R,D\&I management team and the supervisors of the project. In general terms, their activities entail validating the performance indicators, as well as determining if the results conform to what had been predicted, assessing the effectiveness and efficiency of the procedures, difficulties and learning process, and taking account of the benefits to the "stakeholders". The aim of the assessment of the management model was to assist in making improvements to it. This also comes under the responsibility of the members of the R,D\&I management team and the supervisors of the project. Their main activity is restricted to holding a seminar in the following areas: making an assessment of the model, discussing and evaluating the indicators, gathering suggestions for improving the process from those who had formed a part of previous cycles, assessing its capacity to attract a sufficient number of proposals, evaluating the quality of the proposals, investigating the final problems that arose in conducting the management process and determining how problems could be overcome and improvements made in what seemed a systematic way.

\section{Final Considerations}

This project has proposed to develop an integrated management model with research, development and innovation for companies from Eletrobras Group. On the basis of a field research, it was possible to identify various management models which particularly laid emphasis on creating innovations. On the basis of the data investigated, a model was put forward which must be supported by knowledge management. This would be responsible for systematizing and spreading knowledge generated by the whole company with the aim of supporting the implementation of strategic guidelines defined by the senior management in the Research, Development and Innovation (R, D\&l) sector of the organization.

It is also necessary to have a clear understanding of what competencies are essential for an organization, as well as its development plan, in the function of the sectorial pressure, with the proposed projects that have been selected and implemented. These projects must be aligned with the global strategy of the organization. It is up to the knowledge management to inform and convey the nature of the strategic guidelines for the Research, Development and Innovation Sector by appointing supervisors for the project and managers of R,D\&I in this area, with the aim of ensuring consistency between the various sub-systems of the organization.

Considering these facts, the management of Human Resources (HR) should be involved in this area, which will be responsible for defining a researchers "competencies database" and also by organizing specific training schemes to allow the development of competencies among the groups in organizations that have the fundamental skills to create value to the organization. Thus a greater degree of consistency can be sought between the core competencies of the firm - the competencies that are essential to carry out projects - and the allocation of researchers in the light of their professional competencies. Within the R,D\&I sector, there is a link between the HR sector of the organization and the management of projects that are conducive to the development of specialist skills among the professionals of the organization, which are aimed at seeking an alignment between the competencies of the researchers and workers with the strategic competencies requested by the organization. The development of techniques for allocating personnel such as Pipeline Management and the selection of employees on the basis of their technical skills, represents an important advance in seeking to improve the efficiency of the system as a whole.

We also emphasize the importance of companies carrying out HR policies and practices in the sense of recognizing the value of the R,D\&l professional and keeping him/her in the organization. In underlining this, certain characteristics of this professional must be taken into account - the high costs of training, strategic participation in the product lines of the company, dealing with confidential information, among others.

Even though the development of the DEG Project has allowed companies in Eletrobras Group to broaden their studies in the area of technology and innovation management, it is understood that the attempts to spread knowledge about issues related to technology and innovation management, as well as to support the government's actions in creating an innovative culture in companies in the Brazilian electric sector, must continue in a systematic and unified way.

This study has essentially concentrated on the dynamics of companies and highlighted that the primary objective of the DEG Project has been achieved - that is the development of a management model for technology and innovation. It is the task of each of the companies that took part in the DEG Project to implement it and adjust its procedures and schedules to its own culture and resources available. 


\section{References}

BARBIERI, J. C. (Org.) (2003). Organizações Inovadoras: estudos e casos brasileiros. Editora FGV, Rio de Janeiro.

BARBIERI, J.C. and Álvares, A.C.T. (2003). Inovações nas Organizações Empresariais in BARBIERI, J.C. (Org.) Organizações Inovadoras: estudos e casos brasileiros. Editora FGV, Rio de Janeiro.

BARBIERI, J.C., Álvares, A.C.T. and Cajazeira J.E. (2009). Gestão de Idéias para Inovação Contínua. Bookman, Porto Alegre.

BARNEY, B.J. (|99|). Firm resources and sustained competitive advantage. Journal of Management, USA, I7(I), 99-I20.

CHADDAD, J. M. and Andreassi, T. (2002) O vetor academia-empresa para o incremento da inovação tecnológica. In: Anais do I Congresso ABIPTIn- Associação Brasileira dos Institutos de Pesquisa Tecnológica. Curitiba.

FONSECA, S.A. (1998). A parceria empresa-universidade gera inovações na empresa? In:Anais do Simpósio de Gestão da Inovação. São Paulo.

FREEMAN, C. and Soete, L. (1997) The economics of industrial innovation. Penguin Book, Londres.

HAMEL, G. and Prahalad, C.K. (1995) Competindo pelo Futuro. Editora Campus, Rio de Janeiro.

MINISTÉRIO DO PLANEJAMENTO, ORÇAMENTO E GESTÃO (2008). Estudo da Dimensão Territorial para o Planejamento.Vol.IV - Estudos Prospectivos- Escolhas Estratégicas. Ministério do Planejamento, Orçamento e Gestão, Brasilia.

OECD - Organisation for Economic Co-operation and Development (1997). Oslo Manual: proposed guidelines for collecting and interpreting technological innovation data. OECD, Paris.

SCHUMPETER, J. (1988) A Teoria do Desenvolvimento Econômico. Editora Nova Cultural, São Paulo, $3^{a}$. edição, Série "Os Economistas".

SEGATTO, A. and Sbragia, R. (1996). Cooperação universidade-empresa: um estudo exploratório. In: Anais do I Congresso ABIPTIn- Associação Brasileira dos Institutos de Pesquisa Tecnológica. São Paulo.

SOUDER,W. and Sherman, J. (1994). Managing New Technology Development. McGraw-Hill, New York.
TIDD, J. (Org.), (2000). From Knowledge Management to Strategic Competence: measuring technological market and organizational innovation. Imperial College Press, London.

TIDD, J., Bessant, J. and Pavitt, K. (2008). Gestão da Inovação. Editora Bookman, Porto Alegre.

VASCONCELLOS, M. A. (2009). Prefácio. In: BARBIERI, J.C., Álvares, A.C.T. and Cajazeira, J.E. Gestão de Idéias para Inovação Contínua. Bookman, Porto Alegre.

VASCONCELOS, F. C and Vasconcelos, I. F. G. (2004). Paradoxos organizacionais: uma visão transformacional. Cengage Learning, São Paulo.

YIN, Robert K. (200I) Estudo de caso - planejamento e métodos. Bookman, Porto Alegre. 